\title{
REFLECTIONS ON INTEGRAL AND INTEGRATED HERITAGE CARE AT THE THRESHOLD OF THE THIRD MILLENNIUM
}

\section{LAENEN Marc ${ }^{1}$}

${ }^{1}$ Marc Laenen, Former Director of ICCROM

ABSTRACT: Our living environments are being affected by climate change, increased migrations, aggression due to political conflicts and by new real estate developments which cause new challenges to their cultural heritage resources. The "reflection" attempts to promote an integral and integrated approach for cultural heritage enhancement, integral because all heritage sectors should join forces and integrated in planning following an agreed vision on man and society, guided by the principles of sustainability and standards of quality. Especially the problem of integration of different cultures in an agreed "consociation" is being analysed. Three paths of strategic action are suggested to create the right environment for such approach: a strong advocacy and educational strategy with convincing arguments as an answer to the "why" question, a methodology to implement UNESCO's HUL Recommendation as an answer to the "how" question and a system of interpretation and presentation of cultural heritage as a basis for mutual understanding, respect leading to comparative heritage understanding. The "reflection" is intended to initiate discussions.

KEY WORDS: advocacy, consociation, cultural diversity, cultural heritage leverage, cultural tourism, integral and integrated approach, interpretation and presentation 


\section{Marc Laenen}

The ninetieth anniversary of the Athens Document for the Restoration of Historic Monuments adopted at the First International Congress of Architects and Technicians of Historic Monuments in Athens, 1931, and the tenth anniversary of the Historic Urban Landscape Recommendation issued by UNESCO in 2011 are an excellent opportunity to screen the current situation, to identify new problem areas that have an impact on cultural heritage preservation and to reflect on strategic action by all stakeholders and partners in different fields of heritage care to meet the current challenges.

Since the Athens Meeting important doctrinal texts and guidelines for conservation practice have been produced. The most important international reference after the Athens Meeting still is the International Charter for the Conservation and Restoration of Monuments and Sites, the "Venice Charter", adopted by the members of the Second International Congress of Architects and Technicians of Historic Monuments in 1964, some of which had attended the meeting in Athens. Apart from being a complement to the Athens Document the Venice Charter stressed the importance of history again and was an attempt to "rehumanize" modernist formalism, that considered history as contra productive and promoted constructional and functional rationalism in architectural design as the only way for progress. The Venice Charter codified international principles and standards for conservation and restoration practice of architectural heritage, leaving space for further developments in more specific cases of built heritage. However, prior to its more technical recommendations, the Charter stresses the significance of built heritage conservation in a more general "humanistic" vision in planning, which will be further developed in subsequent charters.

Since the Athens Document and the Venice Charter a panoply of instruments have been put in place: more specific charters and declarations, scientific research and operational institutions, appropriate legal provisions for protection and funding for conservation and restoration, training opportunities and educational programs set the scene for cultural heritage care. UNESCO created frameworks for international cooperation in its cultural heritage related conventions. The International Intergovernmental Organization for the Study of the Preservation and Restoration of Cultural Property, ICCROM, sets innovative trends in research and training in heritage conservation and restoration. ICOMOS produced specific guidelines in different fields of application and in different physical and cultural environments for the conservation and restoration of built heritage. Standards for conservation and restoration of objects and works of art in museums and collections are being studied and promoted in the ICOM Committee for Conservation and for the enhancement of intangible cultural heritage UNESCO drafted guidelines in its Convention on the Safeguarding of the Intangible Cultural Heritage (2003).

How can experts in the different cultural heritage fields join forces using all these instruments to meet the complex problems that we face today is the topic of this reflection. 


\section{New developments since 1964}

Since 1964 two new developments in cultural heritage conservation are important to guide further action: The first one is the shift from a focus on strict conservation practice of buildings to the recognition of the social and environmental value of historic cities and rural settlements in planning, as promoted in the European Architectural Heritage Year, 1975, organized by the Council of Europe and expressed in the Declaration of Amsterdam. The social environmental fabric of historic towns was understood as a workable "human" society model to be enhanced in planning. The Declaration launched the concept of "integrated conservation" and recommended necessary informed participative planning processes and structures by all stakeholders. The idea was further refined in the Burra Charter (1979) and in the Washington Charter on the Conservation of Historic Towns and Urban Areas (1987) followed by practical operational recommendations in UNESCO's Historic Urban Landscape Recommendation in 2011. What was suggested for architectural cultural heritage in the Amsterdam Declaration has been specified in other fields of cultural heritage in UNESCO's Convention for the Safeguarding of the Intangible Cultural Heritage (2003) and the Framework Convention on the Social Value of Cultural Heritage, produced by the Council of Europe and further referred to as the "Faro Convention" (2005). These important doctrinal texts and operational guidelines initiated a movement to promote leverage as an essential qualifying factor in living environment development.

The second important development was the recognition of cultural diversity in the understanding of the notions cultural heritage and its conservation as a result of the "Nara Conference on Authenticity" organized in Nara, in 1994, by UNESCO, ICCROM, ICOMOS and the Agency of Cultural Affairs of Japan. The discussion had been prepared earlier in that year in a workshop organized by Riksantikvaren in Bergen in Norway. The occasion was the proposal for inscription on UNESCO's World Heritage List of the Horyu-Ji temple (Nara) and, following the World Heritage operational guidelines, the condition to pass the "authenticity test", that at that time was based on the application of the European paradigm of authenticity: materials, form, workmanship and setting. The general conclusion was fundamental criticism against universal guidelines and the acceptance of cultural diversity with regard to the notion's cultural heritage and its conservation. The notion "authenticity" was specified as the "credibility and truthfulness" of heritage resources for the values and significances, which they represent and the capacity of their fabric to convey full understanding of their cultural backgrounds. Critical historic research on the resources' "entries" to cultural information: form, design, materials, substance, use and reuse, function, tradition, techniques and craftsmanship, setting and - the more difficult aspects to assess- such as "spirit" and "feeling", supported by other relevant historical resources are expected to lead to the understanding and clarification of the social cultural essence of which the resources are the expression. The Nara conference created a methodological framework for the definition and valuing of cultural heritage, in fact the "authentication" of the resources and the significances that they express. The "Nara grid" in which aspects of heritage resources are confronted with their artistic, historic, social and scientific dimension is a useful tool for such assessments. Following the Nara Conference, the topic was further refined in different cultural environments in the world: in the San Antonio Declaration for the Americas (San Antonio, United States of America, 
1996), in the expert meeting on Authenticity and Integrity in the African Context Zimbabwe for Africa (Zimbabwe 2000) and in the Charter on Authenticity and Historical Reconstruction in relationship to Cultural Heritage for the Baltic area, Belorussia and Ukraine (Riga, Latvia, 2000). In the meantime, the authenticity question is an ongoing discussion.

Another important conclusion of the Nara conference has been the interpretation of cultural heritage as a continuous living tradition. The discussions in the meeting made it clear that in many cultural environments heritage is an ongoing cultural practice of craftsmanship: "the making" and "maintenance" of cultural heritage resources as a vernacular process of participative craftsmanship in building tradition and the production of art and objects in a significant landscape. In the famous Grand Shrine in Ise, in the Mie Prefecture in Japan, the periodical rebuilding of the complex and the maintenance of its landscape together form a traditional Shinto ritual and are heritage practice. In these cultural environments living heritage is a continuous "authentic" performance of a concept and know-how and leading craftsmen in these environments are being recognized as "national treasures". Craftsmanship has never been absent in the process of "making" material cultural heritage in western cultural environments. The intangible component of heritage, that in the XIXth and early XXth century had been especially important for the support of cultural identities, was implicitly present in the Venice Charter, but has been ignored in conservation and restoration practice that focused on the conservation and restoration of material evidence of built heritage. The "Nara alternative" brought the intangible background of tangible heritage to the foreground and considered it as essential. It can be inspirational in other cultures, especially in upcoming heritage industries, where traditional craftsmanship is applied for new "products" using contemporary techniques for design. CRATerre-EAG- International Centre for Earth Construction-School of Architecture of Grenoble applies traditional adobe technique in contemporary building and maintenance in the world. The "Compagnons des Devoirs" and "Compagnons du Devoir" in Europe continue concepts of traditional carpentry using traditional know how and practice for new buildings. They are just a few examples among many others of creative continuity of traditional craftmanship combined with contemporary techniques that are in full development and merit attention.

Apart from this alternative interpretation of heritage one cannot ignore that the final result of "making" material heritage resources in all cultures, the buildings, the archaeological sites, the objects and the works of art in museums have material evidence that can and should be the object of conservation and restoration even when the way of concrete conservation practice may be different. 


\section{Recent developments}

Since these developments the situation in our living environments has tremendously changed, represent serious threats for cultural heritage and require action.

Climate change has its impact on the environmental conditions of cultural property and its conservation: floods and tsunamis wiped heritage resources away. In such circumstances risk preparedness requires priority in funding and planning. Budget restrictions compel governments to review legal protection.

Cultural heritage, which in the past has been in several cases an argument for political conflicts, but in more cases an opportunity for cross-cultural exchange and growth, has become a cause of disagreement in our increasing multicultural environments. On the international scene heritage is being used as a strategic instrument for aggression and destruction. In addition to that a large migration movement because of political conflicts and increasing poverty causes problems in coexistence for hosting societies and newcomers.

New large-scale market and capital driven real estate developments breakthrough in historic cities, rural settlements and landscapes, destroying the carrying capacity of their historic fabric for a society on a human scale. In the same sense new worldwide concentration of economic and political power and information technology connect people as never before. Yet these developments may be detrimental for the preservation of their cultural specificity.

On the other hand, postmodern criticism against existing large and broad connections and systems and its subsequent relativism and deconstructivism encouraged further development of regionalism. Cultural heritage is being used as a powerful instrument to support cultural identity, but can feed extreme nationalism, cultural fundamentalism, fake identity construction and polarization in our immediate living environments and on the international scene.

Since the early charters, the notion of heritage has been expanded from material to immaterial, from elitist to popular and from past to present. Much has been "heritagized" and the notion risks inflation if one does not remain critical to its essence. UNESCO's Convention on the Intangible Cultural Heritage and the Faro Convention offer a clear definition of what is understood by cultural heritage: "expressions, tangible and intangible", "without ownership", of "continuously changing values, beliefs, knowledge and tradition.....that govern "interaction between man and environment"... "inherited from the past". These expressions are culturally specific and connect individuals in "heritage societies" in a shared social space, in which their specific cultural identity is understood and confirmed.

Values, knowledge, beliefs and traditions in their turn are significant of a more general sociocultural background, a "Zeitgeist", that permeates feelings, thought and above all decisions in the interaction between man and environment, following a vision on an agreed or imposed model of man and society, or being the result of decisions taken by governments on economic, political or ideological grounds. In the current definitions the difference between mere "cultural history" and "cultural heritage" lies in the significance of heritage resources for members of heritage societies in shaping their cultural identity and the feeling of safety connected with it. Heritage is 
emotional, an "experience", rather than being a question of rational investigation for knowledge increase as it is the case for historiography. In the current understanding the notion can and must be seen as a kind of "appropriation" of resources by heritage society members because of their role in their identity experience and their enhancement for the future. In this context it is easy to understand that heritage society members don't make a distinction between tangible and intangible resources in their onsite heritage experience. Both intangible and tangible heritage are the object of an interwoven experience by society members: rituals, traditions and values are being experienced "somewhere" in the social space, using "intrinsically significant" objects and works of art. The distinction between tangible and intangible is an intellectual and analytical approach to a complex reality.

Nevertheless both, cultural heritage and history are important sources of information about values, beliefs, knowledge, traditions .....and about decisions and their consequences on man and environment. Both can be inspirational in a constructive and critical discussion of the future of ever-changing societies, the difference being that historical resources arekept for their informative value about history and heritage resources for their leverage potential in development.

\section{From "identity" to "identities"}

However, some aspects need precision. Firstly, the notion "cultural identity" is not a "monolithic", homogenous reality. It has multiple aspects within the same cultural tradition: "sub-identities" such as heritage communities linked to age, to profession, to religion, to leisure, to sports, or sub-identities linked with differences in religion, ethnicity or language. Furthermore, the same cultures may be present in larger regional, national or continental contexts. In addition to this, migrants and their value systems and heritage resources settle down and join local living environments. Their right to "be themselves" has been legitimized in the Universal Declaration of Human Rights of 1948 and confirmed in UNESCO's Convention on the Protection and Promotion of the Diversity of Cultural Expressions (2005). We move from rights "of" cultural heritage to rights "to" cultural heritage. The result is a "consociation" of individuals and heritage societies, a multifaceted reality, determined by a "multicolored mosaic" of "identities" in the same living environment.

Nor is cultural identity a static reality. It is in itself subject to change. UNESCO's Conventions and the Faro Convention interpret identity as a dynamic process: Values, beliefs, knowledge and traditions change overtime. Some practices, such as slavery, child labor, gender or racial inequity, that used to be practices harbored by some societies in the past, have been or are being abandoned or should be. They were practices based on political, economic or ideological basis in many cases at the detriment of existing traditional values. We would not name them "values" anymore because we are inclined to understand the noun "value" as a "quality" and not as just a custom or practice. Other values, beliefs or traditions eroded and have been revisited, reinterpreted and renovated and obtained a new significance for society members, corresponding to them at that time valid value interpretations. Changes in visions in religion in western cultures 
changed rituals, buildings and their interiors and the use of significant ritual objects and works of art. In some cases, the basic spiritual essence of religious buildings has been abandoned in favor of reuse for community oriented administrative or commercial functions. In these cases, keeping form prevailed to maintaining substantive essence. In palaces, houses, gardens and interiors the understanding of social status, space, luxury, comfort, cosines and beauty changes continuously. The same goes for the evolution of knowledge: knowledge is always provisional and subject to revision or further refinement. In most cases changes were inspired by new insights, new knowledge and new visions on man and environment, in many cases forthcoming from distinct cultures and were each time reviewed and recalibrated. At the same time new trends were adopted and locally interpreted following a dialectic process of abandonment, renovation and innovation. One can conclude that both", identity" and "heritage" are always in a process of "becoming".

\section{Heritage and space}

One of the aspects of heritage that merits specific attention is the anchorage of heritage in living environments. Cultural heritage is a cultural and spatial discourse. Both are structurally connected: We are who we are in the space and the time in which we are, a result of an ever-changing reality in an ever-changing environment. All successive interpretations and implementations of values, beliefs and traditions leave their footprints in environment and turn our living environments into specific "cultural landscapes" in the strict sense of the word. They form a compact stratification of different cultural layers. These footprints are "authentic", that is to say, "truthful and credible" expressions of these changing values, beliefs, traditions and decisions, fuse into the social space and define its specific character. Still heritage experience in space does not include "ownership" of the social space and certainly not exclusive use, as nationalism in the XIXth and XXth century used to claim. The social space is a shared environment, a "consociation" where individuals and different heritage societies are living together and have the "right of land use".

However, planning of living environments is a responsibility of governments and supersedes what is happening on grassroots level in heritage societies. Not every outcome of planning has been the result of a humanistic vision of man and environment and a participative approach and is certainly not "cultural heritage" that society members would consider as significant for their identity. Still national and regional governments expect the established environment to be a connecting argument and to offer a sense of belonging. The results of planning are part of landscape's character. We therefore may want to understand that the identity and the "spirit" our living environments, our cultural landscapes, are multilayered and multicultural realities. 


\section{Living environments: our "inheritance"}

We can have another view on our cultural landscapes, our living environments, and understand them as a complex "inheritance" and start from there for in our actions: In fact, we "inherit" our complex living environments. They are our "inheritance". As "heirs" we are responsible for their future. History is a living movement, continuously subject to change and in every planning, we are facing a new "momentum of authenticity" that is expected to be "credible and truthful" for the values which we adhere today and that will leave their footprints on the existing layers of our cultural landscapes. We expect for this new layer a development policy that is based on a shared vision on man and society, guided by the principles of societal sustainability and the standards of quality of life, hoping to contribute to "wellbeing" or "better being" of our societies in their environment. As heritage professionals we are expected to ensure leverage of all heritage resources, tangible and intangible in such process following the Historic Urban Landscape Recommendation.

In the given circumstances the objective is a workable and convened social environment, a "consociation" where all heritage societies, including minorities, coexist not without the perspective in the long term of a "symbiosis", a term borrowed from biology, where flora and fauna biodiversity is essential for survival of species. In our environment cultural diversity is essential for existence and cross-cultural exchanges a vehicle for growth. We imagine a kind of integrative "consociationalism" rather than an assimilation with leading cultures.

In defining a common vision of man and society we face the problem that different cultures have a different vision on man and society and subsequently of quality of life. They treasure different values or different interpretations of similar values, all of them implementing their own vision on man and environment. The Universal Declaration of Human Rights in 1948, that mainly is considered as a universal reference, has been criticized and has its regional applications in regions where religion prevails to other civil rights.

However, in our living environments different cultures are coerced to live together which creates a field of tension in discussions on how a shared workable "consociation" can be obtained, which values are to be kept and what can be integrated. It is a discussion on a balance between interests of individuals or specific societies and those of the overall community.

Immigrants, that settle down in new fully grown cultural environments, face a problem of "identification" with and in a new environment without losing their specificity in an assimilation process. Having left their homeland, where their identity has been shaped, and therefore being "homeless", they are confronted with a "foreign country", with a very different physical and cultural environment, where other values are being applied and where they are expected to accommodate with "the others". The challenge of a consociation is the integration of differences in the same environment, in finding a "Lowest Common Multiple" implicitly present in all differences, relevant for all and accepted by all.

The problem is the same everywhere in the world. This observation has its consequences for an integral and integrated planning policy and will be a theme of debate in the resumed discussions 
on a regional, national or continental "Leitkultur" leading culture, especially in a period of time with increasing migrations. In some cultures, a leading culture is validated and imposed on religious, economic or political grounds, in other environments it is the result of a democratic process. Still in all political systems the imposed or grown value system needs acceptance and compliance. An attempt to share a vision in a consociation presupposes an open mind and an environment for continuous joint reflection on which vision on man and society, which quality standards should be drafted and how coined values can revisited, clarified and put in perspective. Therefore, periodical critical review, analysis, understanding and clarification of current values is indispensable. It is a learning process that will require advocacy and education and sense of public responsibility, in democratic environments a bottom-up development of a shared culture.

One of the first conditions is a forum for intercultural dialogue that would lead to comparative heritage understanding and mutual respect. Heritage professionals of all heritage sectors, tangible and intangible and representing all cultural realities are expected to help creating the necessary conditions for such an environment.

Three paths of action may be useful for an integral and integrated approach: firstly, the creation of a culture for conservation by means of advocacy and education as an answer to the "why question", secondly a working model to answer the "how question" and thirdly an intercultural dialogue-oriented system of interpretation and presentation of cultural heritage.

\section{Towards a "culture for conservation": sensitization by means of advocacy and education: the "Why question".}

All stakeholders need information about the fundamental "why question" prior to entering consultation or debate on the "how question". The objective is to create a culture for conservation. In that perspective it may be useful to repeat the main argument for cultural heritage conservation and stress again that cultural heritage reminds us of our roots, avoids "amnesia" and is vital for cultural identity experience. In complex living environments we think of collective memory: We include in the discussions the voice of all heritage societies, that ever in the history of our cultural environments have contributed to their specific character. They render their historic participation in development present, useful and meaningful. Their presence in planning turns their contribution from "history" into "cultural heritage".

However since "space ownership" is abandoned and when the social space should become a common space, a "consociation" where all cultures can settle in and thrive, we need to investigate how our historic towns rural settlements and ultimately our cultural landscapes can become a collective environment for all. Their social and environmental value is a very important argument, on top of the individual or community-specific discourse. That priority is being recognized by heritage professionals but not by all stakeholders, especially in the environment of real estate development agencies, governments and the local population, that is the most important stakeholder in the whole process. We therefore need convincing results of good practices, where the creative enhancement of historic urban centers, rural settlements and landscape proves to be 


\section{Marc Laenen}

beneficial for the quality of multicultural living environments.

Finally, if we think in terms of the "sustainability" of our heritage resources we may want to recognize that a homogeneous culture, a monoculture, that would equalize the multicolored mosaic of our living environments into a common monotonous "grey"(?) color with different shades, is contradictory to the essence of the cultural diversity of human nature. Culture is as diverse as environments are and will continue to be diverse. It is the essence of the consociation concept. The idea of "sustainability", that has been applied in economics and natural resources to maintain economic resources and biodiversity and has been resumed in cultural resources in the context of cultural diversity is to be understood as its "persistenceness", its "maintainability". "Persistenceness" of cultural diversity is the way to sustain humanity in its diversity. We are dealing with the continuity of a system and support and further develop our cultural diversity and its social psychological potential for self-knowledge and knowledge of "the others' ("We need more than one mirror to know ourselves") and its role for evolution and growth trough crosscultural exchanges. Such ideas may be developed in formal and informal education programs.

Towards an integral and integrated approach in cultural heritage practice, the "How question".

Firstly, we cannot stop ongoing necessary efforts for preventive and curative conservation of our material heritage resources. That work should not be abandoned.

However, in the context of the development of our inherited environments, all heritage professionals are invited to join forces for a strategy on integral and integrated heritage practice. In all heritage sectors the earlier mentioned creative continuity of the basic intangible component of cultural heritage has an enormous potential.

The "how question" is expected to effectively leverage all cultural heritage in planning towards a shared vision on man and environment, the standards of quality and the principles of cultural diversity's "persistenceness" hoping to reach a new sense of a connectivity for all in a "consociation". The Universal Declaration of Human Rights and UNESCO's Convention on the Protection and Promotion of the Diversity of Cultural Expressions represent a general understanding of humanistic existence and a vision on humanity and ethics even without God and can orientate action. UNESCO's Historic Urban Landscape Recommendation is a useful tool.

The application of standards of quality needs further refinement. The Davos Declaration for Built Environment can be a first reference. Among other criteria we certainly include safety: a world without righteous wars but with righteous peace, a sound social and physical environment, a social inclusive policy, a sense of identity and pride for all, a viable economy, respect for collective memory and efficient, transparent governance.... A sort of "quality experience" for all: for the local inhabitants and for their visitors. Such approach is in fact a further step in "civilization", a step in a process of growth to a more "civil" society. The noun "civilization" indeed harbors the verb "civilize" and points to action and improvement. All stakeholders are involved in a shared "civilization process".

Relevant results are expected from a critical constructive scientific research on heritage resources' capacity to contribute to a shared environment: A first "archaeological critical historical research 
on heritage "entries", as they mentioned earlier, would deliver insight, understanding and clarification of heritage resources' significance for the cultural backgrounds that they represent: the Zeitgeist, in which they were valued and more specifically their social and cultural significance.

The second step in the investigation process would be research on their susceptibility, their carrying capacity, for new interpretations and reformulations, which are significant for our ways of thinking and acting today, in other words their potential for recalibration as it has been done in the past. In that perspective confrontation with the shared vision and with the standards of quality will be the test for their leverage. Here the discussion cannot avoid the problems on the limits of change, that have been debated in sessions of the ICOMOS 'International Scientific Committee for the Theory and Philosophy of Conservation in 2011.It is fundamentally an ethical question that relies on scientific rigor and honesty.

We have to accept that in principle a "cancel culture" is not an option and that all heritage resources deserve a critical research on their potential in planning. If conclusions of such research are negative, abandonment of existing practices need motivation and documentation before being passed from "heritage" to "history". Finally, in so far critical research has been honest and truthful we have the right to make mistakes in our decisions.

It would be advisable to set up pilot research programs in different parts of the world, in different cultural environments, where the same problems of integration of migrant culture with local leading culture occur, to identify relevant success factors and best practices in the different cultural environments and train professionals.

Towards comparative heritage understanding: the interpretation and presentation of cultural heritage resources in the context of intercultural dialogue.

The importance of intercultural dialogue is being recognized by all international and regional organizations. "Opening up" or the "interpretation and presentation" of cultural heritage resources is a vehicle for dialogue with other cultures and for a comparative understanding. It can be done in education and advocacy initiatives and in cultural tourism.

The tourist industry indeed has discovered heritage tourism as a lucrative market and, being an economic sector, operators set quantitative success factors for good quality offerings to measure success, not without collateral damages on heritage resources and hosting environments in overvisited sites.

On the other side heritage and cultural tourism offer "enriching cultural experiences", an increased self-knowledge and knowledge of other cultures past and present in their environment. Such knowledge leads to cultural development and can under some conditions lead to the "mutual understanding, respect for cultures and peaceful coexistence" that all documents put forward. The International Charters on Cultural Tourism (1999) and on the Interpretation of Cultural Heritage Sites, the so called Ename Charter (2008), issued by ICOMOS' International Scientific Committees, set conditions for a responsible approach, backed up by the Global Code of Ethics issued by UNWTO (1999). 


\section{Marc Laenen}

However, if we want to market our offerings in the perspective of intercultural dialogue we need narratives with substantive information, the right accents and significant heritage resource selection tailored to different sorts of audience.

With regard to the narrative, we would expect a substantive "informative experience" that makes visited sites and communities in their environment known and understood. We don't expect stories about bricks and mortar or mere facts and dates nor simplified and stereotyped imaging, but an "experience" of authoritative and significant information about the way of life of human beings past and present: the significances of their heritage resources for the values that society members treasure in their mind and in their heart while practicing their rituals, their myths, their social celebrations, their hosting traditions, while planning their settlements, building their houses, decorating their interiors, their know how while practicing their craftsmanship, their arts, their feelings and ideas while writing and performing poetry, music and drama, always in relation to the environment. We expect these backgrounds to move to the foreground in interpretation and presentation.

It is obvious that the quality of the narrative depends on the credibility and truthfulness of the resources and of the unbiased position of the researcher and the mediator: for dialogue we need at least two parts involved, one being the visitor, the guest, the other being the living host community and its heritage and cultural resources. The local population, especially while practicing their cultural rituals and traditions will be the right partner for such encounters. Attending "genuine" community life, more than staged performances for tourists, is a valuable immediate source of information and experience. On the other hand, "silent" heritage resources need mediators. Mediators are the architects of the information transfer. They facilitate a confrontation or - if well designed- an intercultural "dialogue" with "silent" heritage resources. The presentation of the results of research into a meaningful narrative and format of delivery is a delicate matter for mediators not without risk to produce biased constructions that would serve cultural myths, fake identity constructions or political ideologies. Results are expected to be conclusions of scientific research. Still conclusions in communication programs remain subjective interpretations and sometimes mere constructions. They are basically relative, provisional and in their turn changeable.

In addition to the substance of a narrative the way of information delivery is important. We need tailored programs for different categories of audience. Experience has proven that performative entries to the substance such as genuine theatre, concerts and visits to craftsmen at work are sometimes more effective than educational intellectual entries, on condition that they are not staged performances for tourists, a fake authentic experience as an answer to escapism for identity confirmation or just for fun. Therefore, a combined product of intellectual and performative entries can be very effective.

In addition to these first observations two accents may be effective in information transfer: Experience in the cultural biography approach in Lazio (Italy) pointed out that horizontal and vertical connections in the narrative are important to connect cultures: horizontal links between all heritage sectors and contemporary culture and links with other cultures in the same period of 
time on the one hand and topic related vertical links in the past on the other. Both links connect civilizations and show that all people in all times and all cultures faced the same problems. The broad field of cultural anthropology is an excellent framework for theme and site selection. Such narratives give an image of what humanity has been and still is. They support our cultural differences. In theory one can imagine a Grand Tour of humanity following the example of the late XVIIIth and XIXth century tours by intellectuals and artists that is now would be available for many.

However if we want our narative to be effective for mutual understanding the identification of what we have in common with other cultures past and present and the clarification of these differences facilitates a breeding ground for reflection, discussion and debate on a common future.

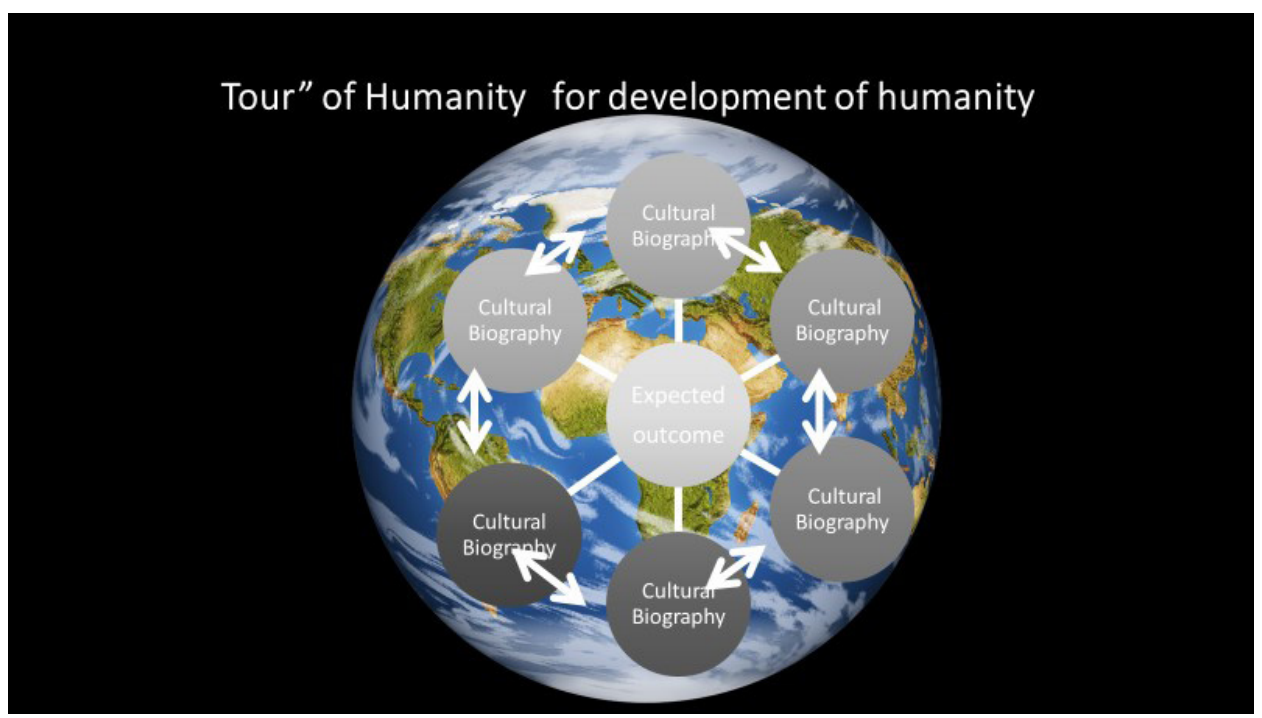

The cultural biography is not the only way to understand cultures and other methods will have similar or different results. We may need to evaluate the effectiveness of different working methods and set qualitative success factors. Quantitative measures have their importance since we are inclined to address an as large as possible audience. However as important if not more important are qualitative measures of success that would measure the impact of working methods on the brains, the heart and the attitude of site visitors. Both quantitative and qualitative criteria are elements in a marketing strategy of cultural/heritage tourism. The next challenge will be to set up a system of qualitative measures of success for different approaches and for and in different cultural environments, hoping to reach a broad set of operational and methodological recommendations.

These considerations do not detract from what we did and what we will continue to do in cultural heritage care. They only orientate what we can do together to promote awareness and responsibility in ensuring cultural heritage leverage in planning in the given circumstances. They are only intended as a start for further discussion. 


\section{Bibliography}

(The) Athens Charter on the Restoration of Historic Monuments,1931.

Choay F., Sept propositions sur le concept d' "authenticite" et son usage dans les pratiques du patrimoine historique, The Nara Conference on Authenticity in Relation to the World Heritage Convention, Nara, Japan, 1-6 November 1994, Proceedings, UNESCO, Agency of Cultural Affairs ( Government of Japan) ICCROM, ICOMOS, Trondheim, 1995.

Council of Europe, European Charter of Architectural Heritage, Strasbourg,1975.

Council of Europe,. Convention on the Value of Cultural Heritage for Society (Faro Convention), Strasbourg, 2005

Davos Declaration: Eight Criteria for high quality Baukultur, Swiss Federal Office for Culture, Davos,2020.

De Dijn H., Levende geschiedenis: geënsceneerde authenticiteit?, [in:] Streven, 77, 10, 2010.

De Dijn H., Drie vormen van weten over Ethiek, Wetenschap en Moraalfilosofie, Kalmthout, 2017. European Union: Towards an integrated approach to cultural heritage for Europe, Communication from the Commission to the European Parliament, the European Economic and Social Committee and the Council of regions, Brussels, 2017.

Falser M. S., From Venice 1964 to Nara1994-Changing concepts of authenticity? [in:] Conservation and Preservation, Interactions between Theory and Practice. In memoriam Alois Riegl ( 1858 1905), Proceedings, of the International ICOMOS scientific Committee for the Theory and the Philosophy of Conservation and Restoration, Vienna 23 - 27 April 2008, Florence, 2010.

Heidegger M., Der Ursprung des Kunstwerkes, Frankfurt am Main, 1950.

Houbart C., Raymond Lemaire(1921-1997) et la conservation de la ville ancienne. Approche historique et critique de ses projets belges dans une perspective internationale, Diss. Leuven, 2015.

ICOM. Déclaration ICOM-FMAM sur le tourisme culturel durable dans le monde entier, (Décembre,2007)

ICOMOS, The Charter on Historic towns and Urban Areas, (The Washington Charter),1987.

ICOMOS, The Charter for the Conservation of Places of Cultural Significance (The Burra Charter)1979, reviewed and adopted version 2013.

ICOMOS, The International Charter on Cultural Tourism, 1999.

ICOMOS, The Charter for the Interpretation and Presentation of Cultural Heritage Sites, (Ename Charter), 2008.

(The) International Charter for the Conservation and Restoration of Monuments and Sites (The Venice Charter), 1964. 
Jokilehto J., Authenticity a general Framework for the concept, [in:] The Nara Conference on Authenticity, Nara, Japan, 1-6 November 1994, Proceedings, UNESCO, Agency of Cultural Affairs (Government of Japan) ICCROM, ICOMOS, Trondheim, 1995.

Jokilehto J., Questions of Authenticity, www.iccrom.org/sites/default/files/publications/2020-05/ convern8_02/jjokiletho_ing_pdf.

Laenen M., Reflections on Heritage Values, [in:] Values and Criteria in Heritage Conservation, Proceedings of the International Conference of ICOMOS, ICCROM, Fondazione Romualdo Del Bianco, Florence 2th - 4th March 2007 Florence, 2008.

Laenen M., From heritage conservation towards its "social fruition" for society and humanity: the multifaceted interpretation and presentation of the "cultural biography" of living environments for cultural dialogue, [in:] Heritage and Landscape as Human Values - proceedings, Proceedings of the Symposium held at ICOMOS' 18th General Assembly, Florence, Italy, 9-14 November 2014, Napels, 2015.

Laenen M., Building Peace trough Heritage, some observations on the interpretation and presentation of heritage sites as a contribution to peace, [in:] Proceedings of the Scientific Symposium on Building Peace trough Heritage, World Forum to Change trough Dialogue, Florence, 13th-15th March, Firenze, 2020.

Larsen E. K. (ed), The Nara Conference on Authenticity in Relation to the World Heritage Convention, Nara, Japan, 1-6 November 1994, Proceedings, UNESCO, Agency of Cultural Affairs ( Government of Japan) ICCROM, ICOMOS, Trondheim, 1995.

Lipp W., StulcJ., Szmygin B., Giometti S. (ed), Conservation Turn-Return to Conservation, Tolerance of Change,Limits of Change, ICOMOS, International Scientific Committee for the Theory and Philosophy of Conservation and Restoration,May 5th-9th,Prague/Cescy Krumlov, Czech Republic, March 3th-6th, Florence,2011, Firenze,2012.

Lowenthal D., Changing Criteria of Authenticity, [in:] The Nara Conference on Authenticity in Relation to the World Heritage Convention, Nara, Japan, 1-6 November 1994, Proceedings, UNESCO, Agency of Cultural Affairs (Government of Japan) ICCROM, ICOMOS, Trondheim, 1995.

Ito N., "Authenticity" inherent in Cultural Heritage in Asia and Japan, [in:] Larsen, E.K. (ed), The Nara Conference on Authenticity in Relation to the World Heritage Convention, Nara, Japan, 1-6 November 1994, Proceedings, UNESCO,Agency of Cultural Affairs ( Government of Japan) ICCROM, ICOMOS, Trondheim, 1995.

(The) Norwich Accord, 2009, Finding the Spirit of the Place. Conservation, Communication and Cultural Tourism. Declaration of the United Kingdom ICOMOS Committee on Cultural Tourism, Norwich, 2009.

O’leary B., Consociation, https://pesd.princeton.edu/mode/246.

Perez de Cuellar J., (ed), Our Creative Diversity, Report of the World Commission on Culture and Development, UNESCO, Paris, 1995. 
Report of the Meeting on Authenticity and Integrity in the African Context, Zimbabwe 2000.

Riegl A., Der Moderne Denkmalkultus, Sein Wesen, seine Entstehung, Wien- Leizig, 1903.

(The) Riga Charter on Authenticity and Historical reconstruction in relationship to Cultural Heritage, Riga, Latvia, 23th-24th October 2000.

(The) San Antonio Declaration on Authenticity for the Americas, 1999.

Selfslagh B., Europese erfgoedconventies, hulpmiddelen en nieuwe uitdagingen, [in:] Een verleden landschap? Erfgoedzorg vandaag en morgen, nieuwe uitdagingen, Provincie Limburg, Tielt, 2006.

Spelsberg I., Cultural Landscape - an expanding notion and its challenges for conservation, [in:] Conservation and Preservation, Interactions between Theory and Practice, In memoriam Alois Riegl (1858 - 1905), Proceedings, of the International ICOMOS Scientific Committee for the Theory and the Philosophy of Conservation and Restoration, Vienna 23 - 27 April 2008, Florence, 2010.

Stovel H., Origins and Influence of the Nara Document on Authenticity, [in:] APT bul, 39, (2-3), 2008.

Tomaszewski A. (ed), Values and Criteriain Heritage Conservation, Proceedings of the International Conference of ICOMOS, ICCROM, Fondzione Romualdo Del Bianco, Florence,March 2th-4th, 2007, Firenze, 2008.

Tomaszewski A., Giometti S. (ed), The Image of Heritage, Changing Perceptions, Permanent Responsibilities, Proceeedings of the International Conference of the ICOMOS International Committee for the Theory and the Philosophu of Conservation and Restoration, March 6th-8th, Florence, 2009, Firenze, 2011.

Tomaszewski A., From Athens 1931 to Venice 1964, History and actuality, [in:] Conservation and Preservation, Interactions between Theory and Practice. In memoriam Alois Riegl ( 1858 1905), Proceedings, of the International ICOMOS scientific Committee for the Theory and the Philosophy of Conservation and Restoration, Vienna 23 - 27 April 2008, Florence, 2010.

UNESCO Convention concerning the Protection of the world Cultural and Natural Heritage, 1972.

UNESCO Convention for the Safeguarding of the Intangible Cultural Heritage, 2003.

UNESCO Convention on the Protection and the Promotion of the Diversity of Cultural Expressions, 2005.

UNESCO Historic Urban Landscape Recommendation, 2011.

Van Balen K., The Nara Grid an Evaluation Scheme Based on the Nara Document on Authenticity, www.jstor.org/stable/25433951.

Verpoest L., Authenticité patrimoine historique et projet de conservation et restauration, [in:] Laurent Debailleux (ed), Patrimoine et Authenticité, Conférence-débat. Actes de la Conférence, Université de Mons, 05 May 2020, Université de Mons/Polytechniqe, Mons, GAV, 2021.

YAMAMOTO Declaration on Integrated Approaches for Safeguarding Tangible and Intangible Cultural Heritage, http://portal.unesco.org/culture/en/files/23863/10988742599yamoto_ declaration, (5.11.2009). 